\title{
sciendo
}

Polish Cartographical Review

Vol. 50, 2018, no. 1, pp. 47-56

DOI: 10.2478/pcr-2018-0001

ROMAN WYTYCZAK

Ossoliński National Institute

Wrocław, Poland

romanwytyczak@onet.pl

\section{Usage of the Atlas of Silesia from 1752 in European cartographic publications}

\begin{abstract}
The author discusses adaptations of maps from the Atlas of Silesia published by European cartographers in more important atlases and multi-sheet maps from the second half of the 18th and early 19th century. Thanks to such adaptations the cartographic image of Silesia could be observed far beyond its borders. Its quality varied, however, both in planimetric contents and in relief. While situation was mostly represented rather correctly in relation to the maps from the Atlas of Silesia, presentation of orography largely differed from the original as well as from its real character. Even application of three methods of relief presentation on a single map did not bring on proper results, mainly due to the fact that the authors of adaptations did not know Silesia.
\end{abstract}

Keywords: old maps of Silesia, situational contents of maps, relief presentation on maps in the 18th century

\section{Introduction}

In the summer of 1752 , after many years of hindrance, Atlas Silesiae (the Atlas of Silesia) was published by the famous publishing house of Homann Heirs in Nuremberg. It had been 30 years since the Emperor Charles VI of Austria commissioned J.Wieland, the main author of the Atlas, to elaborate maps of the Silesian duchies. One of the reasons of such delay was that Silesia went under the rule of Prussia as a result of the first Silesian war in 1742.

The new ruler of Silesia, King Frederick II the Great had had an opportunity to become acquainted with several maps of Silesian duchies before subordinating the land on the Odra river, because since 1730s they had been sold separately by Homann's company through the Korns bookstore in Wrocław (M. Hanke 1935, p. 334; B. Horodyski 2002, p. 103). The king had another contact with them in 1741 after the battle of Małujowice (Mollvitz), victorious for Prussians. M. Schubarth, the other author of the Atlas, was wounded during the battle on the Austrian side, and his original Silesian maps became a part of the loot of the winners (M. Hanke 1935, p. 141).

\section{Maps of Silesia}

Having no maps of Silesia of his own, Frederick II reckoned that the obtained materials could be used for military purpose. Therefore he forbade their further sale, and most importantly any updating of Homann's maps. For his own use he ordered a generalized mapping of the Prussian province at the scale of $1: 275,000$ which had been executed in 1744 (K. Lindner 1987$, p. 55,174$)$. It can be considered as one of the first adaptations of the work of Wieland and Schubarth, immediately classified by the King and remaining in the manuscript ever since.

It soon became evident that further war to keep the gained territory required better maps than the ones captured before ${ }^{1}$. Because of that Frederick II issued an order to perform a special military mapping of Silesia, which was done in 1747-1753 under supervision of C.F. Wrede and which consisted of 200 sheets at the approximate scale of $1: 33,000$. When the work

\footnotetext{
${ }^{1}$ Maps of duchies from the Atlas were used by Austrians during Silesian wars. First mappings serving military purpose appeared were done in Austria in 1763, after the wars had ended.
} 
on the project was almost finished, the King allowed publication of the Atlas Silesiae, which had been ready for 2 years and which appeared with the already printed date of 1750 . Wrede's map was used by the Prussians in the third Silesian war, known as the seven-year war (1756-1763).

The Prussian king showed interest in the cartography of the subordinated province, which is evident in the large number of elaborations, not only of military character, which were prepared during his rule. Many of them presented fortifications of Silesian fortresses (e.g. Wrocław, Świdnica, Brzeg, Głogów) as well as other urban areas. Three new topographic maps of Silesia were elaborated (L.W. Regler, F.W. Schmettau, W. Hammer). Studies devoted to economic activity were also prepared, e.g. maps of rivers, forested areas or cartographic presentations of settlements in the area of Opole and Strzelin on the base of Wieland and Schubarth's maps of the Duchies (M. Hanke 1935, pp. 171-240).

However, all this considerable output was not publicly available, but rather kept in the royal collection (Königliche Plankammer) in the form of classified manuscripts. Therefore it could not have influenced the development of cartography in Silesia. As a matter of fact, in the second half of the 18th century in Silesia there appeared almost no cartographic publications for public use ${ }^{2}$. Thus the Habsburg Atlas Silesiae ${ }^{3}$, as the first official work of cartography of Silesia, added to the new map image of the province which was already Prussian at that time. It happened as a result of adaptation of the Wieland and Schubarth's maps of the Duchies done mostly by cartographers out of Silesia. This process lasted until the 1840s and consisted in adapting atlas maps or using them as bases for current contents.

As a result there appeared quite accomplished general maps of Silesia, four of which

\footnotetext{
${ }^{2}$ For the sake of precision let us note that during that period there appeared subsequent editions of M.Helwig's woodcarved map of Silesia from 1561. They were published in Wrocław in 1765, twice in 1776 and in 1778. All those maps were intended as collectors' items.

${ }^{3}$ Atlas Silesiae id est Ducatus Silesiae generaliter Quatour Mappis nec non specialiter XVI Mappis tot. Principatus repraesentatibus geographice exhibitus, Addita Praefatione qua de Historia huiuis Atlantis agitur auctoritate publica in lucem emissus ab Homannianis Heredibus. Norimbergae 1750 [1752]
}

entered the atlas. They were maps by: M. Haas in two sheets $(1745,1746), \mathrm{T}$. Mayer (1749) and J.Felbiger's map of the Wrockaw diocese (1751) on the base of the maps of the Duchies. A topographic-general map by J. Lidl was also published (approx. 1745) as well as thematic maps on the base of the Atlas: hydrographic (Halle, approx. 1750), economic by K. Hentschel (Nuremberg 1793) and probably the only map elaborated in Silesia in the second half of this 18th century, a rare map by I. Fischer, the topic of which was Silesian Protestantism at the time. It was published in 1773 by the publishing house of F. Günther in Głogów.

In the 19th century there also appeared administrative and general maps with using of base contents, sometimes only with drawing of water network, published i.a. in Augsburg, Berlin, Paris as well as in Wrocław, where since the beginning of the century there had already existed more than a dozen publishing bookstores which also active in the field of cartography (R. Wytyczak 2008, pp. 9-10, 2014, pp. 69-79).

\section{Atlases and multi-sheet maps of Germany and Poland}

The work of Homann was used, in wider sense, in other publications, such as more important various atlases and multi-sheet maps of Germany and Poland. This issue has not been researched so far, although it deserves attention because of, i.a. the exceptional cartographic quality of the Atlas. Table 1 presents more detailed information on these publications. Most of the listed atlases and maps were elaborated during the Enlightenment, at the time of significant development of the knowledge on the Earth due to numerous research as well as scientific and discovery expeditions. They resulted in i.a. an increased interest in maps, which became a significant source of information about the contemporary world, making it possible to not only learn but also to understand it better. Atlases and maps presented in the table are largely compilations of often valuable and well-known cartographic works often created by proficient authors.

\subsection{Atlases of Germany and the World}

One of the first publications using the maps by J.W. Wieland and M. Schubarth was Atlas 
Table 1. Atlases and multi-sheet maps of the world, Germany and Poland

\begin{tabular}{|c|c|c|c|}
\hline Atlases and maps & Authors & $\begin{array}{l}\text { Place and year } \\
\text { of edition }\end{array}$ & $\begin{array}{l}\text { Relief presentation } \\
\text { methods } \\
\text { on Silesia maps }\end{array}$ \\
\hline $\begin{array}{l}\text { Atlas Selectus von allen } \\
\text { Königreichen und Länder }\end{array}$ & $\begin{array}{l}\text { Johann Georg } \\
\text { Schreiber }\end{array}$ & $\begin{array}{l}\text { Leipzig } \\
\text { [after 1750] }\end{array}$ & hillocks \\
\hline Atlas Minor... & Tobias Conrad Lotter & $\begin{array}{l}\text { Augsburg } \\
\text { [after 1772] }\end{array}$ & hillocks \\
\hline $\begin{array}{l}\text { Atlas Topographique et Militaire qui } \\
\text { comprend les Etats de la Couronne } \\
\text { de Boheme et la Saxe Electorale }\end{array}$ & Roch Joseph Julien & Paris 1758 & $\begin{array}{l}\text { hillocks } \\
\text { semi-perspective }\end{array}$ \\
\hline Grand Atlas d'Allemagne... & Johann Wilhelm Jäger & Frankfurt/M. 1789 & $\begin{array}{l}\text { hillocks } \\
\text { semi-perspective } \\
\text { simple hachure }\end{array}$ \\
\hline $\begin{array}{l}\text { Allgemeiner Grosser } \\
\text { Schrämblischer Atlas }\end{array}$ & Franz Anton Schrämbl & Wien 1800 & simple hachure \\
\hline $\begin{array}{l}\text { Schauplatz der fünf Theile der Welt } \\
\text { mit bestaendiger Rücksicht } \\
\text { auf die besten Originalwerke in drey } \\
\text { Theile Zusammengetragen von } \\
\text { einer Gesellschaft Geographen }\end{array}$ & $\begin{array}{l}\text { Franz Johann Joseph } \\
\text { von Reilly }\end{array}$ & $1789-1806$ & hillocks \\
\hline $\begin{array}{l}\text { Karte von Deutschland } \\
\text { im XVI Blatt... }\end{array}$ & $\begin{array}{l}\text { Daniel Friedrich } \\
\text { Sotzmann }\end{array}$ & Berlin 1789 & simple hachure \\
\hline Charte von Deutschland... & Franz Ludwig Güssefeld & Nürnberg 1790 & hillocks \\
\hline Map of the Empire of Germany... & Louis Delarochette & London 1790 & hillocks \\
\hline $\begin{array}{l}\text { Carte Générale de L'Empire } \\
\text { D'Allemagne... }\end{array}$ & Chauchard & Paris 1790 & $\begin{array}{l}\text { hillocks } \\
\text { semi-perspective }\end{array}$ \\
\hline General-Karte Von Teutschland... & Friedrich Wilhelm Streit & Weimar 1810 & simple hachure \\
\hline Carte de la Pologne... & $\begin{array}{l}\text { Józef Aleksander } \\
\text { Jabłonowski, } \\
\text { Giovanni Antonio } \\
\text { Rizzi-Zannoni }\end{array}$ & Paris 1772 & $\begin{array}{l}\text { hillocks } \\
\text { semi-perspective }\end{array}$ \\
\hline
\end{tabular}

Selectus published in Leipzig, probably after 1750. It was printed by the publishing house of the Saxon cartographer J.G. Schreiber, popular at that time. As the title had it, it was dedicated to "a convenient use at schools, during travel and while reading newspapers". Other such publications of that time had similar purpose and were published in small sizes for additional convenience.

The small maps which are of interest to us present generalized Silesian Duchies at the sca- les of approx. 1:350,000 to approx. 1:600,000. As a result an approximate image of the Duchies was created, also because its main elements were presented with some negligence. This refers both to land relief presented by the method of rather primitive hillocks (perspective drawing) and to a seriously distorted river network which occasionally completely differs from the original. It is worth noting that the use of hillock is a step backwards in relation to the Atlas of Silesia where most maps use a new 
method of relief presentation in the form of semi-perspective and where on the map the Duchy of Cieszyn the method of simple hachure ${ }^{4}$, the most modern at that time, is applied. For some of his maps J.G. Schreiber used the two-sheet map of the Lower and Upper Silesia by M.Hass, which was mentioned earlier, and which was an adaptation of the works of Wieland and Schubarth. It remains unclear why the Duchy of Grodków (Duchy of Nysa on Schreiber's map) was presented according to the map of Jonas Scultetus from 1644. As a result of generalization of contents roads disappeared from the map (except the Duchy of Wołów and Ziębice) which certainly limited its appeal for travelers.

A small-format Atlas Minor published in the early 1770 s by T.C. Lotter in Augsburg was of similar character. A detailed comparison of the two publications showed that its maps of the Duchies are based on the adaptations from Schreiber's atlas.

Atlas Topographique et Militaire qui comprend les Etats de la Couronne de Boheme et la Saxe Electorale (Topographic-Military Atlas of the Czechia and Saxony) from 1758 published by the royal cartographer R.J. Julien in Paris was completely different. It appeared in the first years of the seven-year war with a dedication to Maria Theresa, for France was Austria's ally in that war. Silesia in the atlas of R.J. Julien is presented in a general way on five sheets at the scale of approx. 1:230,00. Relief is presented by rows of hillocks, e.g. in Karkonosze Mts., isolated hillocks in other places and also by semi-perspective, e.g. in the Duchy of Grodków. By using such combined method the author attempted to conform the presentation of orography to the maps of the Atlas of Silesia. However, the image of situation, largely projecting the original drawing, was far more successful.

Grand Atlas d'Allemagne (the Great Atlas of Germany) consisted of 81 sheets at the scale of approx. 1:220,000 is one of the more significant cartographic works presenting the 18th century German states. It was the first large

\footnotetext{
${ }^{4}$ Method of semi-perspective depicts relief at the angle of 45 to 60 degrees with lines on all slopes. Simple hachure involves close lines on slopes, often in their bottom section, with peak sections free of lines. See S. Pietkiewicz (1930, p. 4), E. Arnberger, I. Kretschmer (1975, Bd. 1, p. 262), A. Konias (1995, pp. 116, 140, 142).
}

scale map of German territories, made by the military cartographer J.W. Jäger. The Atlas was published in Frankfurt am Mein in 1789 (figs. 1 and 2). The image of Silesia presented on seven sheets has situational contents presented less precisely than on the R.J. Julien's map, while relief quite successfully imitates the drawings of Wieland and Schubarth, perhaps due to the use of semi-perspective and simple hachure, although Jäger used hillocks to present higher sections of Karkonosze Mts.

Allgemeiner Grosser Schrämblischer Atlas, the first Austrian atlas published in Vienna in 1800 was a still bigger publishing project. Its author F.A. Schrämbl was a cartographer and the owner of an established publishing house. Over $70 \%$ of maps in the atlas were reprinted from earlier elaborations and adaptations done by Schrämbl (U. Kohlmaier 2001, p. 62). The latter include a general map of Silesia reduced to the scale of approx. 1:530,0005. Its drawing is precise and clear. Presentation of forest areas is especially expressive. Relief is carefully rendered with simple hachure. Regretfully, it does not reflect characteristic features of Silesian landscape (figs. 3 and 4).

The second atlas, Schauplatz der fünf Theile der Welt , which is today considered one of the greatest in the world, was published in Vienna in 1789-1806. Its author was F.J.J Reilly, the competitor of Schrämbl. This great work consisted of four volumes and contained 830 maps. It constituted a cartographic illustration of Neue Erdbeschreibung by A.F. Büsching, the contemporary description of Europe in ten volumes. Maps of Silesia are in the second volume. There is a very general presentation of the whole province and small maps of separate Duchies, sometimes several of them placed on one page. Their approximate scales range from $1: 460,000$ to $1: 480,000$. Water network is the best visible element of the map. Only some roads are marked schematically, and relief is presented by randomly placed hillocks (fig. 5).

\subsection{Multi-sheet maps of Germany}

Adaptations of the maps from the Atlas of Silesia are also connected with separate multi-

\footnotetext{
5 The same map constituted a part of a separately published Neueste Generalkarte von Deutschland in XXIV Blättern, Wien 1797.
} 


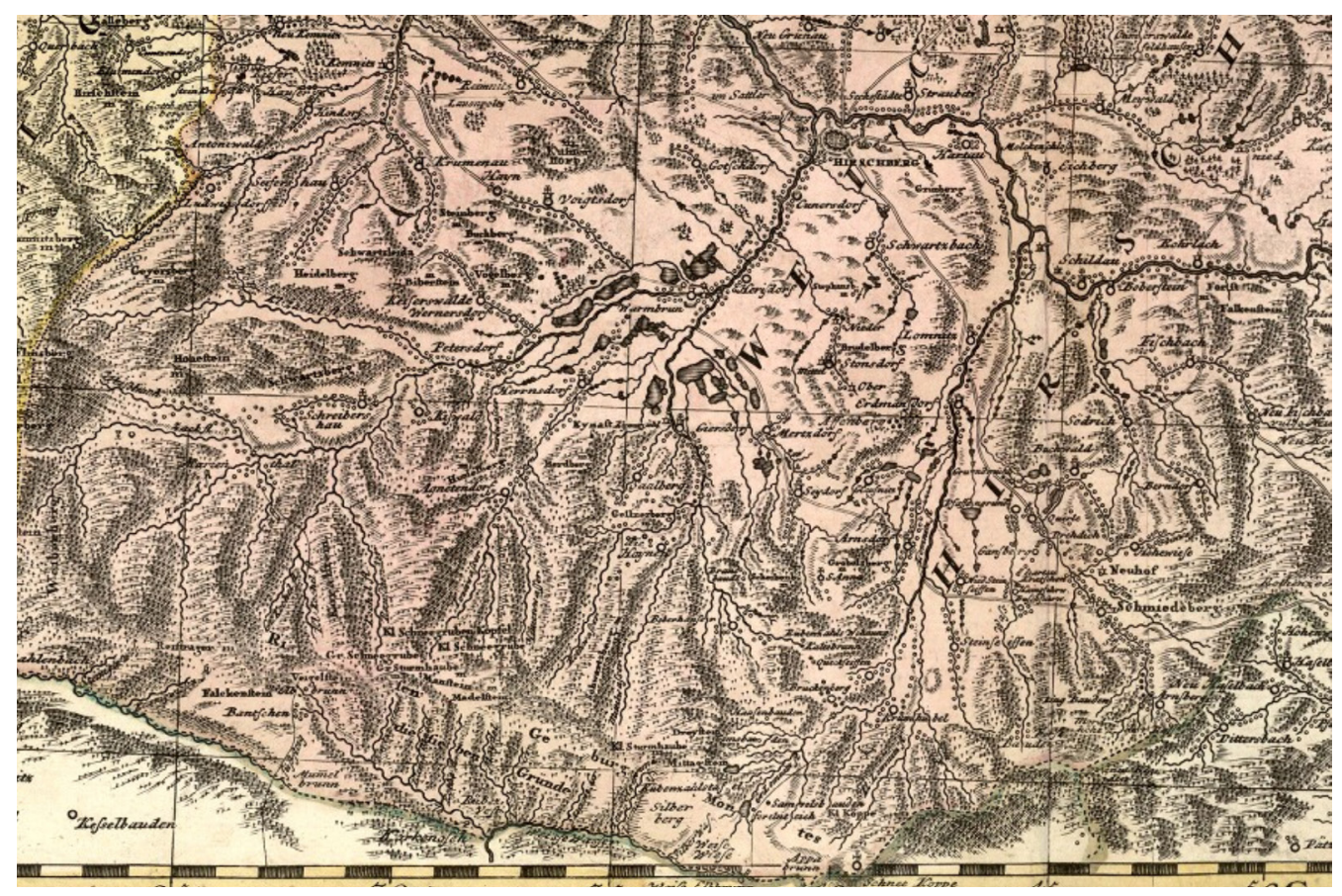

Fig. 1. Karkonosze Mts. and Jelenia Góra Basin on the map of the Duchy of Jawor in Atlas of Silesia from 1752. Relief presented with the method of semi-perspective (source: www.mollova mapova sbirka)

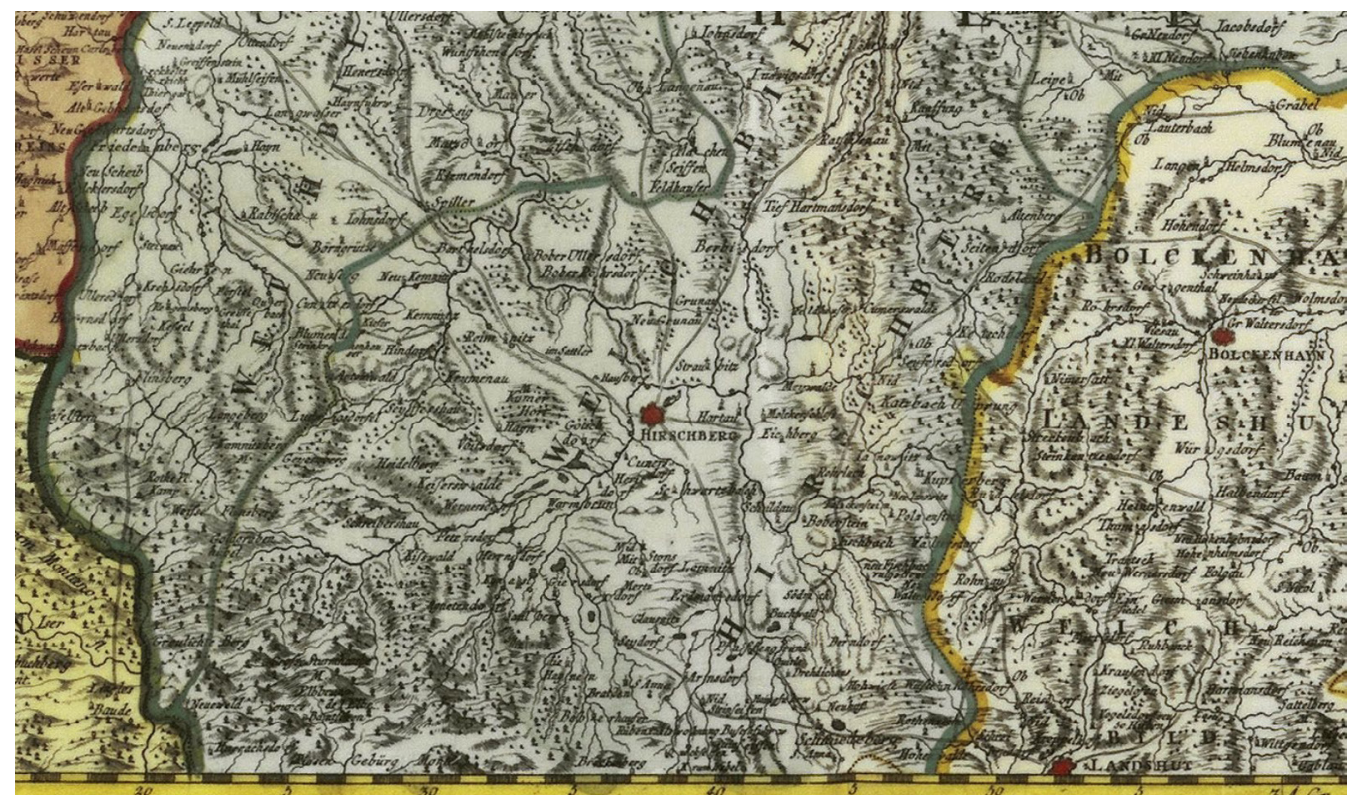

Fig. 2. Vicinity of Jelenia Góra on the map of J.W. Jäger's great atlas of Germany from 1789. Relief presented with three methods: hillocks, semi-perspective and simple hachure (source: www.kartensammlung ryhiner) 


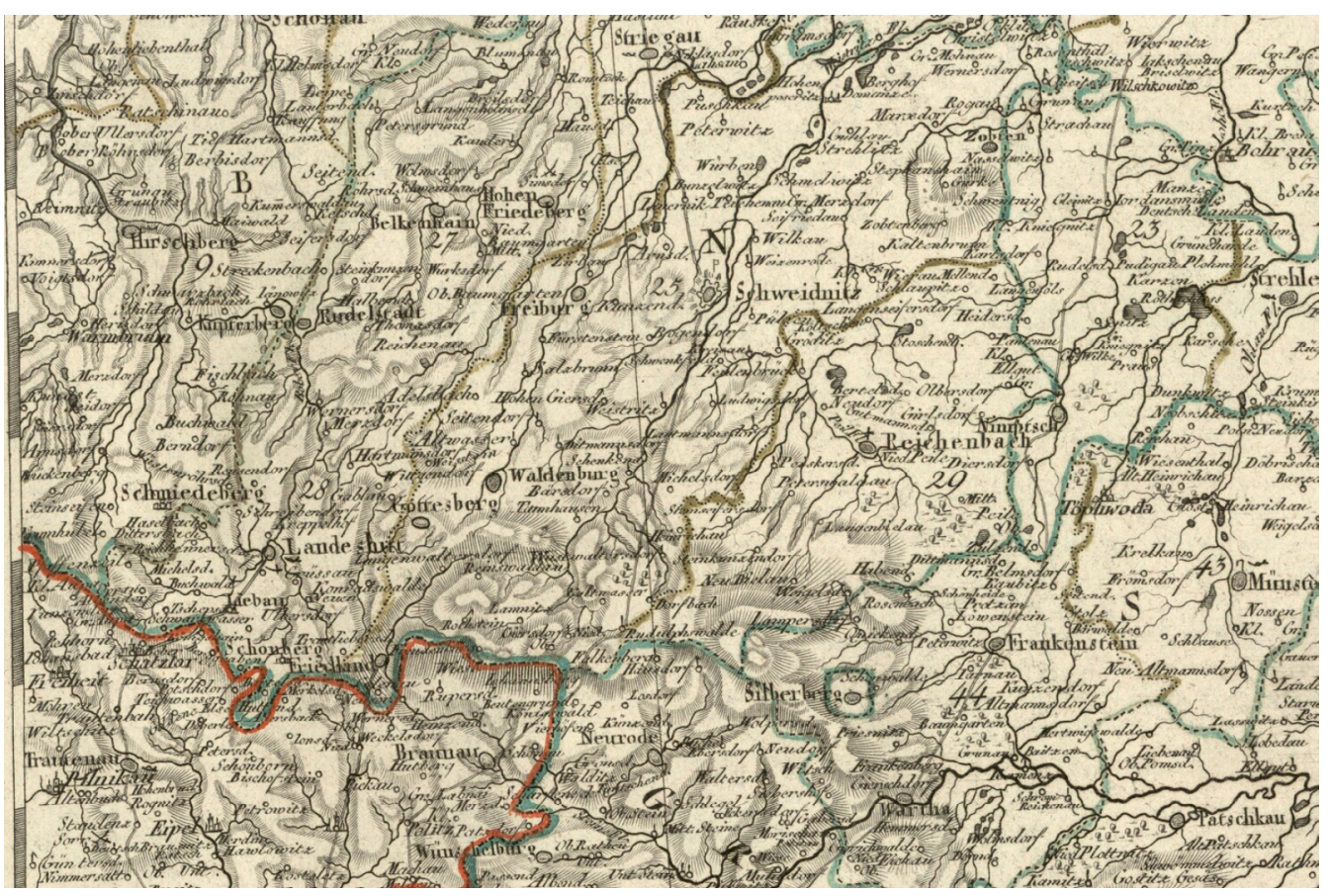

Fig. 3. Sections of West Sudetes and Middle Sudetes with Ślęża Massif and poorly visible Sudetes edge (fault) in F.A. Schrämbl's world atlas from 1800. Relief presented with simple hachure.

The edge of Sudetes on this map lies just next to Świdnica (Schweidnitz), while in reality it is located $4 \mathrm{~km}$ away from the town (source: www.mollova mapova sbirka)

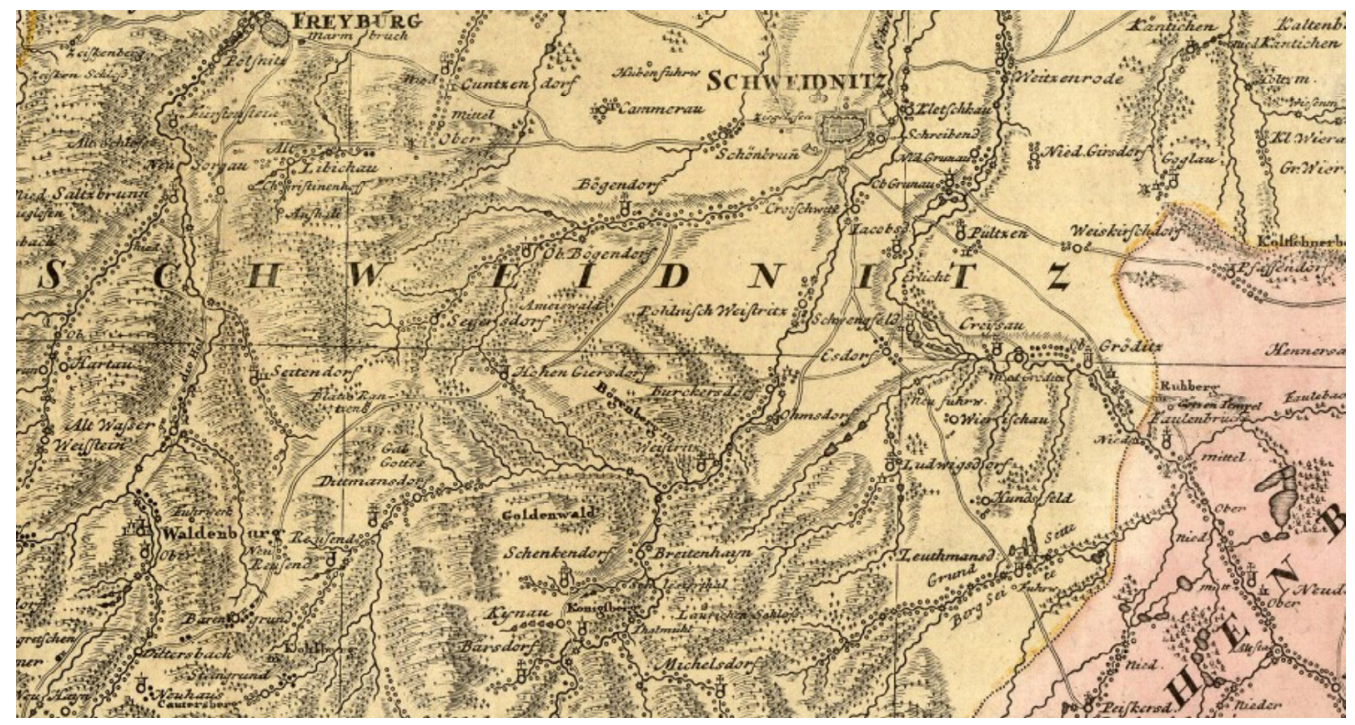

Fig. 4. Section of the Sudetes edge south of Świdnica on the map of the Duchy of Świdnica by J.W. Wieland and M. Schubarth from the Atlas of Silesia (source: www.mollova mapova sbirka) 
sheet-maps of Germany ${ }^{6}$. Among the earliest ones are the two maps elaborated by the well known cartographers D.F. Sotzmann and F.L. Güssefeld. Sotzmann's map was published in 1789 and consisted of 16 sheets at the scale of approx. 1:1,100,000. Silesia on the map is nicely and expressively drawn, with relief presented with simple hachure. Güssefeld's four-sheet map from 1790 at the scale of approx. $1: 1,300,000$ is inferior because of less precisely rendered planimetric contents and relief presented by template hillocks.

The map by the French cartographer L. Delarochette at the scale of approx.1:1,250,00 from 1790 is more accomplished. Its drawing is clear and detailed, main roads are marked, but relief is still depicted with hillocks. mountainous areas is rendered in an interesting way. Chauchard used the method of semi-perspective which gave a rather vivid image of the landscape, although showing little similarity to the original. Higher mountains are presented with rows of connected hillocks of varying size and with detailed relief to make them look more realistic. In Karkonosze Mts. Chauchard added peaks to hillocks to stress the cumulative character of the range. A little smaller rows of hillocks were placed in Izerskie Mts., Wałbrzyskie Mts. and Sowie Mts. As a result of this innovation the image of mountains is closer to the original, i.e. the Atlas of Silesia, but only in some places, e.g. west of Wałbrzych or in the region of the central section of the Kwisa river in Izerskie Mts. (fig. 6).

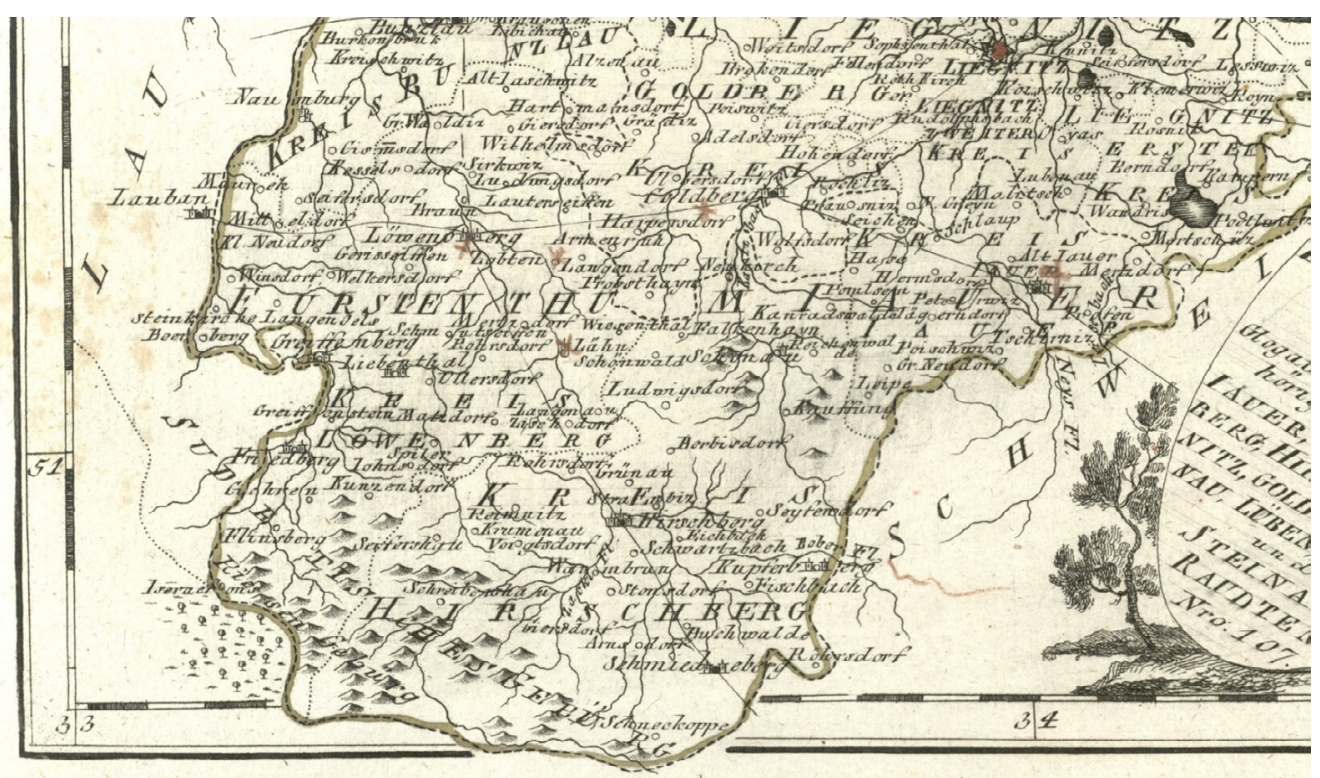

Fig. 5. Southern part of the Duchy of Jawor on the map from F.J.J. Reilly's atlas of Europe (source: www.mollova mapova sbirka)

Carte Générale de L'Empire D'Allemagne in nine sheets at the scale of approx. 1:520,000 from 1790 is one of the more interesting single maps of Germany. It was elaborated by Chauchard, a military engineer. Here the relief of

\footnotetext{
6 The analysis considered maps at the scales of $1: 1,300,000$ and larger.
}

The rare General-Karte von Teutschland (General Map of Germany) from 1810 is noteworthy, also because of its presentation of relief. It was published in four sheets (approx. 1:1,000,000) by F.W. Streit, a military cartographer. The author used simple hachure to present large part of the area on the left bank of Odra river. The most interesting is the image of Sudetes, where 


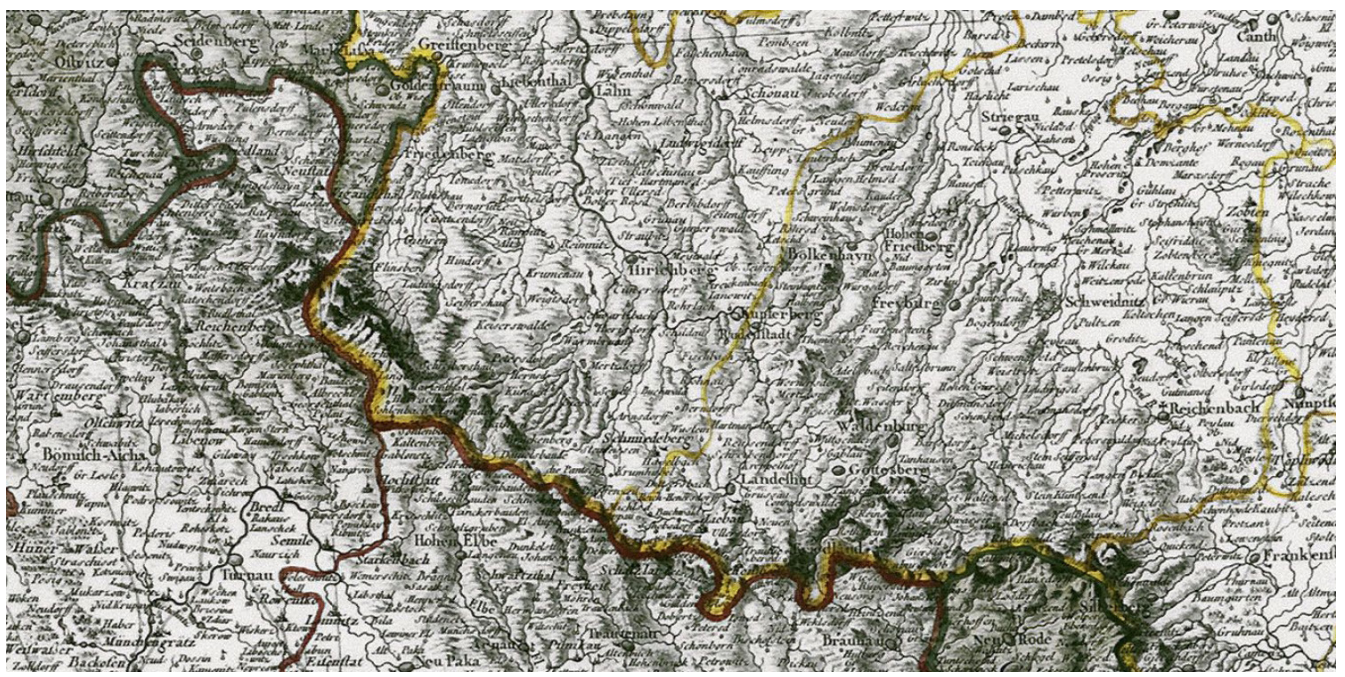

Fig. 6. Southwestern part of Silesia on Chauchard's map from 1790. Relief presented mainly with semi-perspective. Hillocks with added peaks visible in Karkonosze Mts.

(source: www. Kartensammlung Ryhiner)

Streit used "caterpillar"7 drawing, a variety of simple hachure. With this method he symbolically depicted Izerskie Mts., Karkonosze Mts., Wałbrzyskie Mts., Sowie Mts., Bardzkie Mts. and Złote Mts.. The direction of these ranges almost conforms to reality. He also used this method to present some quite fantastic elements of relief: a long mountain range across Sudetes from the area of Bolesławiec and Chojnów towards Boguszów and then southward to the Czech border. The second "range" follows an arch from Gryfów Śląski towards Szklarska Poręba.

\subsection{Carte de la Pologne by J.A. Jabłonowski and G.A. Rizzi-Zannoni}

Silesia was also presented in the Atlas on series of maps of Poland. The best such adaptation is on the great Carte de la Pologne by J.A. Jabłonowski and G.A. Rizzi-Zannoni, published in 1772 at the scale of approx. $1: 690,000$. As regards the graphic depiction and the level of detail, the image of Silesia does not differ much from other regions. It has simi-

\footnotetext{
${ }^{7}$ Caterpillar method presented mountains ranges in the form of long, winding rows marked with lines on sides, which resembled caterpillars. See R. Wytyczak (2008, p. 24).
}

lar pattern of forests, vividly marked roads and relief rendered in slightly modified semi-perspective. Hillocks in mountainous regions are also unconventional, just like on the territory of the Polish-Lithuanian Commonwealth. Single ones appear in Karkonosze Mts., while hillock ranges symbolize Sowie Mts., Bardzkie Mts. and Złote Mts. Regretfully, the Ślęża Massif, so characteristic for Silesian orography, was omitted (fig. 7).

\section{Conclusions}

Presented review of maps and atlases shows that the great work of J.W. Wieland and $M$. Schubarth was frequently used in important European cartographic publications, especially in the second half of the 18th century. It is worth noting that the Atlas was used not only because of the quality of its substance but also, as we know, because of the lack of other source material. They appeared only in the years 1829-1833 when the whole territory of Silesia was covered by sheets of G.D. Reymann's topographic map at the scale of $1: 200,000^{8}$.

\footnotetext{
${ }^{8}$ Since 1806 Gottlob Daniel Reymann led works on Special-Karte von Deutschland topographic map of Germany, which was initiated by the Prussian king Frederick Wilhelm III. After Reymann's death (1837) map sheets were widely used.
} 


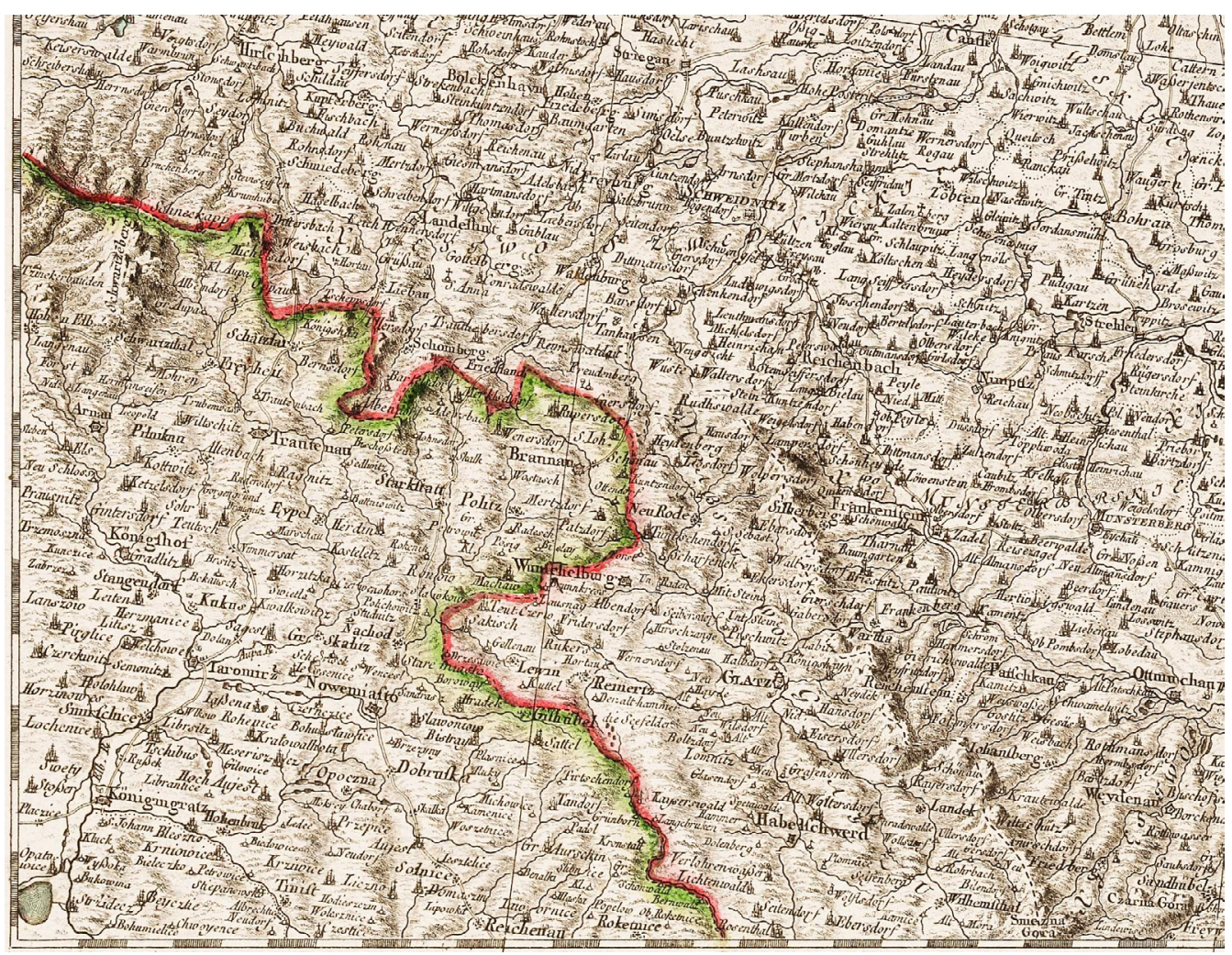

Fig. 7. Part of the Carte de la Pologne by J.A. Jabłonowski and G.A. Rizzi-Zannoni from 1772 presenting Sudetes (source: http://igrek.amzp.pl/mapindex.php?cat=ZANNONICDLP)

The cartographic image of Silesia resulting from the presented adaptations varied. It depended on individual skills and technical-graphic capabilities of particular authors. Ambition was also important, because some authors and publishers (Jäger, Schrämbl, Jabłonowski) considered the social and educational function, while others (Schreiber, Lotter) focused mainly on commercial goals.

The above mentioned differences concerned also the presentation of planimetric contents and relief. In the first case the differentiating factor was the level of detail, which naturally resulted from the scale. Smaller or bigger differences also relate to the level of execution of outline draft. The poorest draft can be seen on maps by Schreiber and Lotter, where i.a. the water network is seriously distorted. Julien, Schrämbl, Sotzmann, Delarochette and Rizzi-Zannoni presented outline draft much more carefully.
Presentation of relief looks different on each map. Before we discuss it in more detail, a few general remarks about presenting relief in the Atlas of Silesia. The method of semi-perspective applied was at the time of its preparation (1722-1750) a modern one ${ }^{9}$. In the 18th century it was used simultaneously with the disappearing method of hillocks and with simple hachure which was growing in significance. Semi-perspective gave quite vivid depiction of relief, and a cartographer well familiar with the terrain could achieve an effect close to reality, to a certain extent accounting for height pro-

\footnotetext{
${ }^{9}$ On the maps by Julien (1758) and Jäger (1789) Upper Lausitz and Czechia which border with Silesia have relief presented with hillocks, which was taken from original presentations of that time. In the first case it was the map of the Kingdom of Czechia by J.C. Müller from 1723, in the second the map by A.F. Zürner (1732) adapted by P. Schenk (the younger) from 1752 .
} 
portions. It should be remembered, however, that the image drawn with the above three methods was intuitional and largely subjective (S. Pietkiewicz 1930, p. 4).

A close look at the presentation of relief on the maps of the Atlas shows that in many places it was rendered quite correctly. Ranges of Sudetes and most of all Izerskie Mts. and Karkonosze Mts. with their division into lateral ranges are easiest to identify. One can notice small, but outstanding Sokole Mts. and distinguish Wałbrzyskie Mts., Sowie Mts. and a large part of Kamienne Mts. ${ }^{10}$. Also the edge of the fault dividing Sudety from their Foreland is well visible. North of the Silesian Lowland one can see the ranges of Trzebnickie Hills and Dalkowskie Hills.

None of the European cartographers who adapted the maps of the Atlas presented the orography of Silesia correctly. J.W. Jäger, who, as we know, applied three methods, achieved an image conforming to the original only with the semi-perspective. However Dalkowskie Hills south of Głogów mentioned above he depicted using a wrong variant of simple hachure,

\footnotetext{
${ }^{10}$ Among the listed Sudetes ranges there are no mountains of the Kłodzko region because in the Atlas there was no map of this region authored by Wieland and Schubarth. Before the takeover by Prussia this land belonged to the Czech crown. To some copies Homann Heirs added the map of the Kłodzko county by T. Mayer from 1747, which was an adaptation of a part of the map of the Kingdom of Czechia from 1723.
}

\section{Literature}

Arnberger E., Kretschmer I., 1975, Wesen und Aufgaben der Kartographie. Topographische Karten. Wien.

Hanke M., 1935, Geschichte der Amtlicher Kartographie Brandenburg-Preussens bis zum Ausgang der Friederizianischen Zeit, Stuttgart.

Horodyski B., 2002, Dzieje Atlasu Śląska 1720-1752. „Zabytki Polskiej Kartografii” Z. 7, Warszawa.

Konias A., 1995, Kartograficzny obraz Śląska na podstawie map księstw śląskich Jana Wolfganga Wielanda I Mateusza Schubartha z polowy XVIII wieku (z oceną kartometryczną). Katowice.

Kohlmaier U., 2001, Der Verlag Franz Anton Schrämbl, Wien.

Lindner K., 1987, Zwischen Oder und Riesengebirge. Schlesische Karten aus fünf Jahrhunderten, Weissenhorn.

Pietkiewicz S., 1930, O sposobach przedstawiania the so-called Plateaumanier ${ }^{11}$, which completely spoiled the original image of relief. Apart from that in Karkonosze Mts. he used isolated hillocks which are entirely unsuitable for presentation of higher mountains.

Until the end of the 18th century hillocks in different variations had been used by most authors of the maps discussed here, although by that time this method was outdated and quite irrelevant.

However, the use of semi-perspective and simple hachure failed to deliver expected results. it is evident in the adaptations by Julien, Chauchard, Rizzi-Zannoni as well as Sotzmann, Schrämbl and Streit. In this case the reason for failing to present a depiction of relief more conforming to reality was the authors' lack of familiarity with Silesia, as well as not very skillful adaptation of Wieland and Schuberth's maps by European cartographers. Their atlas maps and map series had no major influence on the development of cartographic presentations of Silesia, nevertheless for almost 90 years until R.J. Julien's adaptation they had remained the main depictions of the province. It was only since 1845 that the first modern, credible and popular maps prepared and published by the great cartographic publishing house of K. Flemming in Głogów started to be published.

\footnotetext{
11 This variant of simple hachure was described by J. Szaflarski (1972, p. 198) as "lined plateau". Poznanie Tatr, Warszawa, p. 198.
}

terenu na mapach. „Biblioteka Służby Geograficznej" 5. Warszawa.

Szaflarski J., 1972, Poznanie Tatr. Szkice z rozwoju wiedzy o Tatrach do połowy XIX wieku. Warszawa.

Szaniawska L., 1996, Ewolucja reymanowskiej mapy topograficznej Europy Środkowej wydawanej w latach 1844-1874 w Głogowie przez zakład kartograficzny Karola Flemminga. „Czasopismo Zakładu Narodowego imienia Ossolińskich” Z. 7, Wrocław, pp. 89-109.

Wytyczak R., 2008, Śląsk na mapach z lat 1800-1945 w zbiorach Zakładu Narodowego im. Ossolińskich. Wrocław.

Wytyczak R., 2014, Między Scultetusem a Flemmingiem. Obraz Śląska na mapach od lat 30. XVII w. do lat 30 XIX stulecia. In: Znowuż „z kuferkiem i chlebakiem"... Tom poświęcony Wielkiemu Humaniście Julianowi Janczakowi. Wrocław. 